\title{
Зорица ЂЕРГОВИТ-ЈОКСИМОВИЋ \\ О ОБЛИКУ СТВАРИ КОЈЕ ЋЕ ДОЋИ ИЛИ О ВЕЛСОВОЈ УТОПИЈИ
}

Филозофски факултет Универзитет у Новом Саду

Maxim Shadurski. The Nationality of Utopia: H. G. Wells, England, and the World State. New York and London: Routledge, 2020, 212 pp.

О Херберту Џорџу Велсу, једном од пионира модерне научне фантастике, много је писано, али ни изблиза онолико колико тај плодни стваралац заслужује. Слободно можемо рећи да је најчешће делио рецепцијску судбину жанра чијем је процвату можда и пресудно допринео. Има ли кога да није чуо за Велсов времеплов, његовог невидљивог човека, језиве експерименте доктора Мороа или за стравичну инвазију Марсоваца? Све су то данас готово типски концепти научне фантастике, али и популарне културе, и сви су поникли из пера тог изузетно даровитог и плодног писца. Ипак, испрва третирана као лака и јефтина забава за масе, научна фантастика тек је у другој половини 20. века полако почела да стиче статус легитимног књижевног жанра који завређује пажњу академских изучавалаца књижевности. И тада, заправо, из обиља за научну фантастику карактеристичних тема и мотива - попут путовања кроз време, на Месец, или сусрета с ванземаљцима - по којима су Велсови романи и приче постали препознатљиви, у први план избијају његови најозбиљнији и најинтригантнији доприноси жанру, као што су модерна утопија/дистопија, могућност и изазови даље еволуције људског рода, као и последице научних открића, како на појединце тако и на целокупан људски род.

Максим Шадурски (Maxim Shadurski), ванредни професор књижевне теорије и компаративних студија на Универзитету Сједлце у Пољској и уредник часописа The Wellsian: The Journal of the H. G. Wells Society, већ годинама се предано и веома успешно бави изучавањем утопије у најширем смислу те речи и утопијским опусом Херберта Џорџа Велса. Резултат тога су многи радови објављени у угледним научним часописима, као и две монографије на енглеском језику - Literary Utopias from More to Huxley:The Issues of Genre Poetics and Semiosphere. Finding an Island (2007) и Utopia as a World Model: The Boundaries and Borderlands of a Literary Phenomenon (2016). У управо објављеној научној монографији The Nationality of Utopia: H. G. Wells, England, and the World State Шадурски је објединио своја 
интересовања и усредсредио се на провокативна питања односа нације и утопије, те Велсов ултимативни утопијски пројекат стварања светске државе.

Да бисмо разумели Велсове радикалне утопијске идеје, морамо познавати и друштвено-историјски контекст у коме су настале. Реч је о турбулентном периоду који су на глобалном плану обележиле, с једне стране, идеје laissez faire капитализма, те безграничне вере у непрестани, узлазни, напредак човечанства, а с друге стране, социјалистичко-комунистичка учења о нужности укидања капитализма на путу ка остварењу друштва социјалне правде и једнакости. Било је то и време кад Дарвиново учење о еволуцији све више добија на замаху. За свог века, Велс је доживео врхунац британског колонијалног царства, Први светски рат, Октобарску револуцију, јачање фашизма и нацизма, и, најзад, Други светски рат. Млади енглески биолог скромног радничког порекла здушно је пригрлио идеје дарвинизма и учења социјализма. Поред тога што је написао на десетине романа и прича, и антиципирао појаву многих изума, објавио је и мноштво социолошких, историјских и политиколошких дела. Био је и неуморни политички делатник који је у међуратном периоду јурио с краја на крај света не би ли политичке моћнике тог доба упознао са својим идејама како спречити нови светски рат. Френклин Д. Рузвелт и Винстон Черчил били су његови чести саговорници, упознао је и Лењина, интервјуисао Стаљина... У сваком свом делу иступао је против друштвених зала и неправди упозоравајући на странпутицу којом је свет кренуо. Као контратежу растућој друштвеној неједнакости, похлепи капитализма, те све извеснијим глобалним сукобима масовних разарања, истицао је своје социјалистичке утопије, да би, у једном тренутку, ужаснут развојем догађаја у међуратном периоду, почео све снажније да заступа идеју новог светског поретка оличеног у светској држави, о чему је, додуше, први пут писао још почетком 20. века као, на пример, у Mogeрној уйойији објављеној 1905. године. Ипак, умро је потпуно разочаран у људски род, само годину дана након завршетка Другог светског рата који је тако очајнички покушавао да спречи.

Максим Шадурски у својој студији о питању односа (енглеске) нације и утопије најпре полази од дуге традиције утопије у енглеској књижевности, којој је припадао и родоначелник модерног утопијског жанра Томас Мор, који је своју Уйойuјy објавио још давне 1516. године. У поглављу „English Utopia and Utopian England“ [Енглеска утопија и утопијска енглеска] аутор успоставља занимљив реципроцитет између енглеске утопије и утопијске Енглеске јер њих две „размењују енергије већ више од пет стотина година“ (Shadurski 2020: 10). Наиме, у многобројним књижевним утопијама приметан је утицај Енглеске и њене културе, баш као што су у подједнакој мери разне књижевне утопије утицале на даљи развој саме Енглеске. 
И заиста, како нас Шадурски подсећа, неки од најзначајнијих писаца утопијских дела потекли су управо из Енглеске, а поред Томаса Мора, међу њима су Френсис Бејкон, Данијел Дефо, Џонатан Свифт, Вилијам Морис, Херберт Џорџ Велс, Олдос Хаксли, Џорџ Орвел, Вилијам Голдинг, Ентони Барџис, Џ. Г. Балард... И неки ранији критичари уочили су постојање те необично снажне везе између утопијске острвске изолованости и енглеске географије, а међу њима Шадурски издваја Артура Леслија Мортона и Ричарда Гербера. Испитујући однос утопије и (енглеског) национализма код Велса, Шадурски указује на чињеницу да у изградњи глобалног утопијског друштва Велс полази од националне премисе која је, наравно, одређена његовом припадношћу енглеској нацији. Ово је утолико значајније јер, према Шадурском, Херберт Џорџ Велс не само да је, у извесном смислу, преформулисао традиционалну енглеску инсуларну утопију већ је постојећи утопијски дискурс о Енглеској искористио за своју идеју о утопијској светској држави која, парадоксално, баштини најбоље одлике енглеске традиције. Ипак, Велсова утопија не само да преиспитује национални дискурс већ га и подрива и трансцендира. Иако је био изразито антиколонијално настројен, Херберт Џорџ Велс је, парадоксално, сматрао да некадашње комуникацијске и трговачке везе успостављене у оквиру експанзивне британске империје која се простирала на свим континентима могу послужити као модел како повезати међусобно удаљене крајеве нове глобалне утопије засноване на дијаметрално супротним постулатима. Дакле, механизми за лакше успостављање хегемонске експлоатације других нација код Велса прерастају у средства утопијске кохезије и напретка који не познаје неуравнотежени, експлоататорски колонијални дискурс метрополе и маргине.

На основу свега овога могло би се доћи до неколиких погрешних закључака: да Велс, с једне стране, намеће енглески утопијски модел науштрб других националних/националистичких пројеката, те да се, с друге стране, перфидно залаже за некакву завереничку, глобалистичку агенду о револуционарном завођењу светске диктатуре по енглеском (нео)колонијалном моделу. Управо супротно томе, Велс заступа поступан, еволутивни преображај целог света ка утопијском хоризонту једне светске државе у којој нема друштвене хијерархије ни војски, припадност целокупном човечанству је једина постојећа националност, а како становници једне његове утопије кажу, „наше образовање је наша једина влада“. Како Шадурски истиче, велсовска утопија, заправо, није ни космополитска ни национална већ је и једно и друго истовремено (Shadurski 2020: 56).

У наредним поглављима аутор преиспитује основне Велсове утопијске замисли одмеравајући их у односу на утопијске идеје других писаца, па тако, у поглављу насловљеном „England in Transition: Memory, Politics, and Technology“ [Енглеска у транзицији: Сећање, 
политика и технологија], Шадурски контрастира утопијске идеје Херберта Џорџа Велса и његовог утопијског претече Роберта Хјуа Бенсона, који је, као католик, наду за утопијско решење на глобалном нивоу пронашао у тобожњој моћи католичанства да уједини свет. Како Бенсонова утопија, гледано из ове перспективе, има више дистопијских него утопијских тонова и нијанси, Шадурски, јасно, предност даје Велсовом секуларном моделу. У четвртом поглављу, насловљеном „England Redeemed: The Road, the Rose, and the Dream“ "Искупљена Енглеска: Пут, ружа и сан] аутор подробно раз-

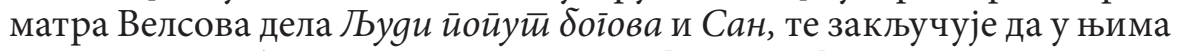
„лојалност либералним вредностима [енглеске] ниже средње класе наговештава Утопију, која се представља као остварење тежњи Енглеске“ (Shadurski 2020: 139). Шадурски потом у поглављу „The End of England: Eugenics, Landscape, and Recollection" [Крај Енглеске: Eугеника, пејзаж и сећање] обрађује начин функционисања Хакслијеве еугеничке Светске државе из антиутопијског романа Врли нови

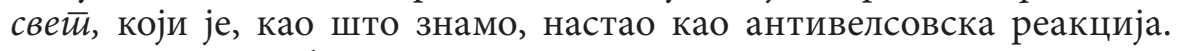
Нису, дакле, сви били одушевљени Велсовим утопијским предлозима, а међу његовим критичарима издваја се, поред Олдоса Хакслија, и Џорџ Орвел, који указује на опасности велсовске постнационалне, глобалне утопије, те антиципира њен преображају тоталитаризам. У закључној коди, насловљеној „England for England’s Sake?“ [Енглеска ради Енглеске?] Максим Шадурски испитује одјеке Велсових утопијских идеја у стваралаштву Џорџа Орвела, али и у делима новијих аутора, попут Ентонија Барџиса, Џ. Г. Баларда и Џулијана Барнса и закључује да се енглеска утопија вратила кући, у Енглеску, али са жаљењем констатује да је сад то некаква постнационална дистопија, те да су велсовске идеје о либерализму и фер плеју остале по страни, заборављене и неискоришћене.

Да закључимо: монографија Максима Шадурског The Nationality of Utopia: H. G. Wells, England, and the World State изузетно је корисно и занимљиво штиво не само за оне који се баве изучавањем утопије и енглеске књижевности већ и питањима нације и националног у оквиру утопијског и/или глобалистичког дискурса. У тренуцима кад се све више говори о потреби некаквог глобалног „ресетовања“, те проналаска глобалног решења за нагомилане проблеме с којима се свет суочава - о чему је и Велс писао, али са сасвим другачијих позиција - при чему смо сви заједно све ближи дистопији, а све даље од утопије, у таквим тренуцима, дакле, потребно је, управо као што је то и Шадурски маестрално учинио, поново критички преиспитати изворне утопијске идеје. 